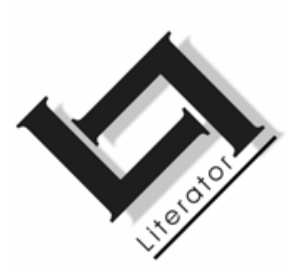

\title{
Johannes Kerkorrel en postapartheid- Afrikaneridentiteit
}

\author{
Martina Viljoen \\ Departement Musiek \\ Universiteit van die Vrystaat \\ BLOEMFONTEIN \\ E-pos: viljoenM.hum@mail.uovs.ac.za
}

\begin{abstract}
Johannes Kerkorrel and post-apartheid Afrikaner identity

The music of Johannes Kerkorrel (Ralph Rabie, 1960-2002) gave expression to the sentiments of a young white urban generation that rebelled against the autocratic rule of the apartheid government. Kerkorrel's songs, many of which were banned during the apartheid era, created an alternative Afrikaner voice through biting social criticism and political satire.

His politicised narratives evoke collective memories and experiences that construct moral hierarchies by means of an exceptional intensity, simplicity and power. Kerkorrel's life-story may be read as a continuous textual reconfiguration of identity throughout which an uninterrupted thread of self-remembrance is simultaneously woven. In a society in the process of constant transformation, a speculative theorising of Kerkorrel as a construct of local identity may serve as a starting point for understanding popular music representations of the postapartheid Afrikaner character.
\end{abstract}

\section{Opsomming}

Johannes Kerkorrel en postapartheid-Afrikaneridentiteit

Johannes Kerkorrel (Ralph Rabie, 1960-2002) se musiek het die sentimente van 'n jong wit stedelike generasie verwoord wat rebels gestaan het teenoor die outokratiese dispensasie van die apartheidsregering. Kerkorrel se liedjies, waarvan talle gedurende die apartheidsera verban is, het deur middel van bytende sosiale kritiek en politiese satire 'n alternatiewe "Afrikanerstem" gekonstrueer. 
Sy gepolitiseerde narratiewe roep kollektiewe herinneringe en ervarings op wat hiërargieë van 'n morele orde met 'n ongewone intensiteit, eenvoud en krag weergee. Kerkorrel se lewensverhaal kan gelees word as 'n voortdurende tekstuele "hervergestalting" van identiteit waardeur daar terselfdertyd 'n ononderbroke draad van selfgedagtenis vleg. Binne 'n steeds transformerende samelewing kan 'n spekulatiewe teoretisering van Kerkorrel as lokale identiteitskonstruk dien as vertrekpunt om populêr-musikale voorstellings van postapartheid-Afrikanerskap te verreken.

\section{Inleiding}

Ongeveer 'n jaar na die dood van Ralph Rabie (alias Johannes Kerkorrel), het 'n groep Afrikaanse akteurs en musikante 'n konsert ter nagedagtenis van hom op die planke gebring. Die geleentheid het plaasgevind in die Staatsteater, Pretoria, en daar is ' $n$ DVD van die geleentheid vrygestel onder die titel Johannes Kerkorrel: 'n jaar later ... in die Staatsteater. ${ }^{1}$ Die produksie het sommige van sy bekendste liedjies ingesluit, asook beeldmateriaal van Kerkorrel wat sy eie musiek sing. Dit was geen gewone rock-konsert nie, maar eerder 'n ontroerende "portret" van 'n introverte kunstenaar wat 'n betekenisvolle invloed uitgeoefen het op Afrikaanse protesmusiek, asook op 'n jonger generasie linksgesinde wit intellektuele.

Wie was hierdie man? Dit is die vraag wat medekunstenaars Jana Cilliers en Grethe Fox tydens die Kerkorrel-gedenkgeleentheid gestel het. Gedurende die dae, weke en maande wat op Rabie se dood gevolg het, was dit die kernvraag van 'n ongekende getal bydraes op LitNet - en dit bly steeds 'n vraagstuk wat deur middel van joernalistieke betragting ondersoek word. Op die omslag van Willem Pretorius (2004) se onlangse biografie, Kerkorrel, word Rabie aangehaal: "Ek speel Johannes Kerkorrel. Hy is net 'n karakter. Ek speel hom op die verhoog en ek is gek daarna."

Ofskoon Rabie 'n onderskeid gemaak het tussen sy openbare en private selfheid, beweeg my bespreking in hierdie artikel vrylik tussen die personae "Rabie" en "Kerkorrel". Tydens 'n onderhoud vermeld Rabie dat die pseudonieme wat lede van die Voëlvrybeweging aangeneem het die absurditeit van die samelewing waarvan hulle deel was, moes weerspieël. Hulle wou ook die

1 Die kunstenaars wat hieraan deelgeneem het was Jana Cilliers, Grethe Fox, Valiant Swart, Amanda Strydom en Karen Zoid, asook die Nederlandse sanger Stef Bos. Die konsert het plaasgevind op 19 November 2003. 
kulturele identiteit wat daarmee geassosieer is, belaglik maak (aangehaal in Byerly, 1998:20). Sy eie wisseling tussen verhoogname (Johny K, Johannes, Johannes Kerkorrel) dui op 'n bepaalde vloeibaarheid van identiteit wat ook in sy persoonlike lewe aanwesig was.

Die betekenis van Kerkorrel as kunstenaar en die vraag na sy identiteit is nog nie binne die plaaslike musikologie op beduidende wyse in oënskou geneem nie. Soos Stephanus Muller (2002) dit in 'n koerantskets stel, is daar selfs in gebreke gebly om kennis daarvan te neem "dat dit reeds duidelik is dat Kerkorrel in breë kultuurhistoriese verband 'n belangriker musikale figuur is as menige kunsmusiekkomponis wat met religieuse toewyding in konservatoria oor die land bestudeer en gekanoniseer word". Kommentaar op sy werk skram weg van 'n interpretasie van die "suiwer" musikale parameters van sy kuns - hoewel Muller tereg daarop wys dat "Kerkorrel se musiek (die note) nie produktief aan dieselfde eksegetiese druk onderwerp kan word as wat mens op 'n Beethoven-sonate sou kon toepas nie".

In hierdie artikel beoog ek geen formele ontleding van Johannes Kerkorrel se aanwending van musikale elemente nie. Ek poog om tekstuele moontlikhede te omraam waardeur sy identiteit as kunstenaar "gelees" mag word. Gevolglik fokus ek op 'n spekulatiewe konstruksie van sy kreatiewe individualiteit deur middel van die willekeurige saamvoeging van 'n aantal tekste en diskoerse - 'n verband waarbinne daar weliswaar momenteel gefokus word op aspekte van musikale genre. ${ }^{2}$ Binne die bestek van hierdie oogmerk hoop ek om enkele vrae te stel wat mag lei tot verdere kritiese - en moontlik veral ideologies-kritiese - besinning. Eerstens bespreek ek kortliks 'n aantal resente benaderings wat moontlikhede bied vir die konstruksie/rekonstruksie/dekonstruksie van die self.

\section{Die (re)konstruksie van die self}

Gedurende die afgelope dekades het minstens ses benaderings binne die kritiese sosiale denke gestalte gekry. Hierdie benaderings het die meer tradisionele, dikwels klaarblyklik vanselfsprekende grondslae vir die teoretisering van selfheid en van identiteit

$2 \quad$ Hierdie artikel is 'n verwerking van 'n referaat getiteld "Who needs identity? The alternative voice of Johannes Kerkorrel", gelewer by die simposium Music and Identity, Stellenbosch, 24 en 25 November 2004. Die geleentheid het deel gevorm van 'n voortgesette navorsingsprojek oor musiek en identiteit en is aangebied deur die Swedish-South African Research Network. 
aangeveg. Kruiskulturele analise het verskeie minder afgebakende moontlikhede vir die Westerse konsep van die persoon gesuggereer. Op soortgelyke wyse bied die feministiese weergawes van die patriargale konstruksie van die sosiale, historiese en psigologiese terreine 'n radikaal alternatiewe blik op sowel individuele as kollektiewe selfheid. Sosiale konstruksionisme argumenteer dat die self 'n sosio-historiese konstruk is en geen natuurlike objek nie. Sodoende word die idee van die onafwendbaarheid van dominante Westerse verklarings van die self en van identiteit toenemend onder verdenking geplaas (Sampson, 1991:1).

Vanuit die metodologiese perspektief van die sisteemteorie is ' $n$ epistemologiese posisie gepostuleer waarin ontologiese voorrang aan groepsverhoudinge eerder as aan die individu verleen word (Olds, 1992). Hierdeur word die entiteitgebaseerde Westerse ideaal opnuut onder druk geplaas. Kritiese teorie, daarenteen, bevraagteken nie alleen die veronderstelde onontkombaarheid van die genoemde ideaal nie, maar suggereer dat die self hoofsaaklik "ontwerp" is om ideologiese agendas te dien, en sodoende dikwels tot sosiale reproduksie eerder as tot humanitêre vooruitgang bydra (Abbinnett, 2003).

Meer onlangs het dekonstruksie alle aanspraak op die primaatskap van die subjek (die "outeur" van die self) ondermyn. As hoofeksponent van hierdie stroming bevraagteken Jacques Derrida (1981) die identiteitsteorie deur middel van 'n destabilisering van die logika waarop opposisie en hiërargie berus. Sy meesterkonsep, différence, vang hierdie komplekse dekonstruktiewe proses vas deur die suggestie van 'n paradoksale "nieteenwoordigheid" (die tussenruimte; die spasie; die gaping; die spoor). Différence ontken die logika van identiteit (die logika van "albei/of") deur middel van 'n beklemtoning van die logika van die supplement ("albei/en"). Derrida se dekonstruktiewe aanval op teenwoordigheid en identiteit suggereer daarom 'n proses met nóg begin nóg einde.

In hierdie artikel steun ek op aspekte van 'n "neorekonstruksionistiese" benadering. Neorekonstruksionistiese filosofie trag om (rasioneel) geartikuleerde beskrywings (rekonstruksies) te bied van sisteme, strukture of fenomene, terwyl dit terselfdertyd mag aspireer om hierdie beskrywings met 'n bepaalde kreatiewe vryheid - of selfs 'n dekonstruktiewe speelsheid - te "herskryf'. In terme van die teoretisering van selfheid en van identiteit bied hierdie interpretatiewe raamwerk dus ruimte vir spekulatiewe denke wat terselfdertyd berus op verantwoordbare diskoersanalise. Gevolglik kan dit onderskei word van meer radikale vorms van kontemporêre 
denke. In hierdie verband fokus ek op die werk van die filosoof Johann Visagie (1994).

Binne die genoemde teoretiese opset word identiteit aan die subjek toegeskryf volgens die wyses waarop dit binne die bepaalde diskoerse vergestalt word. Identiteit as sodanig gekonstrueer is nie slegs talig van aard nie, maar tekstueel. In hierdie verband moet daarop gewys word dat die model van die teks aanvanklik gedomineer het binne die hermeneutiek, net soos die taalmodel binne die semiotiek die botoon gevoer het. Aspirasies tot 'n meer universele hermeneutiek (of semiotiek) het die idee van die teks egter uitgebrei na dié van tekstualiteit, wat alle geskrewe, gedrukte of verbale tekste insluit, asook alle wyer, relatief outonome semantiese totaliteite wat deur die geskrewe of gesproke woord gemedieer word. Hierdie totaliteite sluit visuele voorstellings, musikale uitinge, ensovoorts in. Uiteraard is hierdie totaliteite aspekte wat almal op 'n ewe belangrike wyse op die onderwerp onder bespreking sou kon inspeel. 3

Die genoemde konseptualisering van die self en van identiteit is ontleen aan 'n model wat gesuggereer word deur die filosoof Paul Ricoeur (1995). Daar word ook kortliks stilgestaan by die denke van Michel Foucault (1972). Ricoeur redeneer dat selfheid 'n "opdrag" is wat uitgevoer word deur middel van 'n brose mediëring tussen, wat hy bestempel as "die bewussyn van vryheid", en "die gebrokenheid van onvervulde begeerte". Volgens hierdie teoretisering word die moontlikheid van 'n onverdeelde self en van 'n "heel siel" slegs moontlik wanneer die subjek 'n hermeneutiese ompad deur die figuratiewe wêreld van die teks aflê. Gedurende hierdie "reis" ontwaak die onderdrukte, verskraalde verbeelding deurdat ongelyksoortige aspekte van realiteit en van die self in sintese gebring word deur middel van kreatiewe figuratiewe interpretasie en - soos Ricoeur (1995:5 e.v.) dit stel - deur middel van die skep van "nuwe metafore".

\section{Die teks as identiteit}

Met hierdie kort teoretiese aanloop in gedagte word vervolgens gefokus op 'n aantal tekste en diskoerse wat Kerkorrel se lewe en werk omskryf. Dit is alombekend dat hierdie protessanger 'n groot lojaliteit teenoor die Afrikaanse taal gekoester het en op onkonvensionele wyse sy eie "taalstryd" geveg het. In 'n onderhoud 
gedurende die laat tagtigerjare verduidelik Rabie dat dit sy missie was om Afrikaans "te bevry" (Brynard, 1999:16). Gedurende die hoogty van P.W. Botha se apartheidsregime kon Afrikaans nie in die stede gepraat word nie, aangesien dit as "die taal van apartheid" té veel bagasie gedra het. $\mathrm{Na}$ aanleiding van die Gereformeerde Blues Band se optredes in die Black Sun in Hillbrow, Johannesburg, asook in The Base in Kaapstad, het ander Afrikaanse kunstenaars die projek begin steun. Teen die tyd dat die eerste alternatiewe rockfees gehou is, het aanhangers in hul duisende opgedaag en was dit duidelik dat die massas, soos Rabie dit stel, "honger was vir protes in Afrikaans" (Brynard, 1989:16).

Op watter wyse kan die protespotensiaal van Rabie se musiek verstaan word binne die interpretatiewe raamwerk wat hierbo geskets is? Dit is nuttig om in hierdie opsig stil te staan by Michel Foucault (1972) se gedagte dat enige vorm van mag 'n sentrale relasionele attribuut is van die vraag na selfkennis. In hierdie verband is dit nie slegs die vergestalting van sosiale verhoudings binne 'n verskeidenheid van diskoerse wat beklemtoon word nie, maar veral die feit dat hierdie verhoudings pertinent as "magsverhoudings" verstaan word. Binne hierdie konteks werk mag egter nie slegs om in te perk of gevange te hou nie, maar ook as produsent van subjektiwiteit. In wese ondermyn Foucault se beskrywing van die self benaderings wat selfheid projekteer as die bloot siniese manipulering van sosiale rolspel. Vir Foucault (1972:131) verpersoonlik selfheid andersheid (différence). Die self word dus nie gekonstrueer as fasette wat na willekeur geselekteer en "uitgespeel" word nie, maar as implisiet teenwoordig in 'n verskeidenheid magsdeurdrenkte diskoerse. 4

Vanuit 'n Foucaultiaanse perspektief sou Johannes Kerkorrel se politiese tekste gelees kon word as diskursiewe uitings wat kollektiewe herinnerings en ervarings van plek en identiteit met ' $n$ buitengewone eenvoud oproep. Hulle mag egter ook as 'n onbestendige spel van politieke mag verstaan word. Sy berugte "Sit dit af" (Eet Kreef, 1989), 'n satire op die alomteenwoordige mediaaanwesigheid van P.W. Botha, grens in meer as één aspek aan die

$4 \quad$ Kritiek op Foucault se denke is welbekend. Ek volstaan hier met Brannigan (1998:207) se waarneming dat Foucault die posisie van diskursiewe formasies in groter detail ontleed as die betekenis daarvan, asook Visagie (1994:56-73) se opmerking dat Foucault se analise van magsrelasies nie ingaan op die formasie van waardesisteme wat binne die kulturele samelewing domineer nie. Gevolglik word geen kriteria ontwikkel om onderskeid te tref tussen normatiewe outoriteit en dominasie nie. 
banale. Die lirieke is deurspek met geykte Afrikaanse kragwoorde, terwyl die musiek op 'n opvallend primitiewe rockstyl steun. Daar is ' $n$ algehele afwesigheid van die melodiese infleksies, stemmingswisselings en intensiewe harmoniese kleuring wat eie is aan hoofstroom rockidiome. Hierdeur word die musiek beperk en verskraal in terme van stilisties-melodiese trefwydte en slaankrag. Hoewel die klavierbegeleiding herinner aan die Amerikaanse rockstyle van die vyftigerjare en blueselemente wat soms aanwesig is, is die eindproduk steeds musikaal gesproke bar en amateuragtig. Dit is egter juis hierdie karige musikale konteks wat aan "Sit dit af" 'n bepaalde "straatgeloofwaardigheid" verleen.

In die stadium toe die album Eet Kreef vrygestel is, was die meeste liedjies daarop deur die destydse SAUK verban. Ofskoon beperk en selfs "oneg" in terme van musikale konsepsie - is die rockstyl deur die Nasionale Partyregering gesien as 'n simbool van protes en die antitese van Afrikanerwaardes. Rabie is deur die Veiligheidspolisie geteister, en die Wit Wolwe het sy motor se bande gesny en sy konserte met stinkbomme gesaboteer. Johannes Kerkorrel is in die media beskryf as 'n "ondermynende terroris" en selfs as 'n "sataniese bloeddrinker" (Brynard, 1999:16).

"Sit dit af" kritiseer nie slegs die apartheidsregime van P.W. Botha nie, maar bevraagteken terselfdertyd die partydigheid van die media en die mag wat dit besit om te manipuleer en te isoleer. Die weergawe van realiteit wat binne hierdie kwalik verbloemde verdigsel van diktatorskap na vore tree, is nóg waarheid, nóg illusie. Nogtans is "Sit dit af" nie slegs 'n subversiewe teks en 'n diskoers van protes nie. Hoewel dit 'n uiting van sterkverwoorde politiese satire is, mag dit terselfdertyd gelees word as 'n tekstuele rekonstruksie van Kerkorrel se innerlike "wêreld". Die lirieke roep 'n geografies spesifiek gesitueerde gewaarwording van tyd, ruimte en identiteit op wat intiem saamhang met Afrikanerskap en sterk patriotiese sentimente. Binne hierdie konteks is die woorde "en 'n boer maak 'n plan", nie verkleinerend van die Afrikaner nie, maar eerder 'n kragtige uiting van nasionale identiteit:

Die ander dag toe voel ek lam

ek wou 'n klein bietjie ontspan

en 'n boer maak 'n plan

ek sit my TV set toe aan

jy sal nie glo wat ek sien

op my TV screen

Dit was 'n nare gesig

dit het my heeltemal ontwrig 
dit was 'n moerse klug

dit was PW se gesig

en langs hom staan oom Pik

oe ek dog ek gaan verstik

Vanuit die perspektief dat identiteit gekonstrueer word na aanleiding van die wyses waarop dit binne bepaalde diskoerse vergestalt word, sou geredeneer kon word dat tradisionele wit Afrikanerskap - soos enige ander kulturele konstruk - 'n "fiksie" is waarbinne geskiedenis, ideologie en kulturele praktyk ineenvloei (vgl. Baines, 2004:1 e.v.). Die samestelling van hierdie spesifieke identiteit berus gevolglik op geen onveranderlike, interne essensie nie, maar hang saam met konkrete sosiale verhoudings en die materiële historiese en sosioekonomiese situering daarvan. Binne die apartheidskonteks is wit Afrikanerskap dikwels verstaan as 'n posisionering van mag en bevoordeling en wit hegemonie as 'n konstruk wat geskep en in stand gehou is deur maatreëls van uitsluiting.

Vanaf die vroeë tagtigerjare het die beweging, bekend as alternatiewe Afrikaanse musiek, "van binne" skerp sosio-politiese kommentaar op hierdie eksklusiwiteit gelewer. 'n Ironiese voorbeeld van Afrikanerskap gekonstrueer deur uitsluiting, is die Afrikaanse skrywer en digter Andre du Toit (Andre le Toit; verhoognaam Koos Kombuis) se "Paranoia in Parow-Noord" (Niemandsland and Beyond, 1990):

Ek weet ek is verslaaf aan drank

Ek is oortrokke by die bank

My dogter is 'n 'Boerepunk'

Maar dank God ek's ten minste blank!

Hierdie teks fokus op die ironie van 'n uitwendig-respektabele voorstedelike Afrikanerskap wat berus op die (waan)denkbeeldige fiksie van 'n superieure ras met spesiale voorregte (soos goddelike beskerming). Die teks suggereer egter terselfdertyd elemente van bekentenis (Kombuis se drank- en dwelmverslawing is welbekend) en vorms van lyding wat geassosieer mag word met 'n samelewing wat op ideologiese drogvoorstellings berus. Die verwysing na ' $n$ "Boerepunk" sluit aan by postapartheidsrepresentasies van wit Afrikanerskap wat die behoefte aan hervertolking van die self onderstreep. Christopher Ballantine (2004) se onlangse studie oor identiteit en wit populêre musiek in die nuwe Suid-Afrika bevind inderdaad dat herinterpretasies van selfheid toenemend gekonstrueer word deur kritiek, satire en humor, asook die vorming van "voortvlugtende" identiteit. 


\section{Meervoudiggekonstrueerde identiteitskonsepsies}

Ballantine (2004) se navorsing bevat nie alleen beduidende etnografiese waarde nie, maar lewer belangrike kommentaar op verskralende manifestasies van identiteitspolitiek binne die SuidAfrikaanse musikologie. Hierdie veld word reeds geruime tyd gekenmerk deur 'n strewe na politiese korrektheid, wat hoofsaaklik manifesteer as 'n tipe musikologiese multikulturalisme. Hierdie tendens staan in direkte konflik met die poststrukturalistiese dekonstruksie van die identiteitsvraag, wat reeds herhaaldelik binne die internasionale literatuur as die "dood" van identiteitspolitiek aangekondig is. ${ }^{5}$ Binne die postmodernisme is identiteit nie langer uniform en in besit van 'n gedeelde voorgeskiedenis nie, maar gefragmenteerd en gefraksioneerd; nooit enkelvoudig nie, maar meervoudig gekonstrueer as verskillende, dikwels kruisende of antagoniserende diskoerse, praktyke en posisies. Volgens hierdie perspektief ontstaan identiteit as die resultaat van 'n komplekse spel van magsmodaliteite. Gevolglik word dit gekenmerk deur differensiasie eerder as deur 'n "natuurlik" gekonstitueerde eenheid wat dui op 'n allesinsluitende eendersheid, sonder noemenswaardige interne differensiëring (vgl. Hall, 1996:1-17).

Die plaaslike musikologie streef binne sterk verpolitiseerde reaksionêre paradigmas om essensiële, hipernormatiewe kategorieë in stand te hou wat, soos hierbo aangedui, lynreg teen die grein van postmoderne identiteitskritiek ingaan. Terselfdertyd ontstaan daar in die ideologiese skadu van die apartheidsbestel, binne wit populêre musiekvorme, 'n verskeidenheid anti-essensialistiese identiteitskonsepsies, soos deur Ballantine (2004) duidelik aangedui.

Ballantine (2004:108) wys byvoorbeeld daarop dat kunstenaars aanvanklik uitgelate gejubel het oor die reënboogeuforie van die nuwe Suid-Afrika. Wit sangers en groepe het op verskeie wyses geïdentifiseer met 'n bevrydende postapartheidsorde. Soms het 'n kwasinasionale volksliedstyl die "nuwe begin" aangekondig (Phillips, 1993), of die vryheid van Madiba gevier (Goosen, 1996). Rassistiese terminologie is omgekeer deur 'n blanke gehoor aan te spreek as "wit kaffir(s) van Afrika" (Goosen, 1996), of as "Almal Kaffers" (Kombuis, 1997).6 Plaaslike swart tale is by Afrikaanse tekste gevoeg (Goosen, 1992; Rauch, 1995) en swart musici in uitvoerings

5 'n Spesiale uitgawe van die New Literary History (Albertini et al., 2000) is as geheel gewy aan die vraag: "Is daar lewe ná identiteitspolitiek?".

6 Vergelyk ook name van plaaslike rockgroepe soos byvoorbeeld "White Trash". 
ingesluit (Kerkorrel, 1992; Rauch, 1995). Ook binne Engelse tekste is daar gefokus op die nuwe politieke bestel. James Phillips en The Lurchers het byvoorbeeld in die liedjie "Moses" (Sunny Skies, 1993) die volgende kwalik verbloemde figuratiewe verwysing na president Nelson Mandela ingesluit: 7

Hey Moses your'e back with a smile, huh! who's gonna say it's from the Sacred Cow? say Moses I think your'e the best please don't turn out like all of the rest

Hey Moses you put a smile on my face Can you save this place

Say Moses I think your'e the best

Please don't turn out like all of the rest

Die nuutgevonde ekstase was egter van korte duur (Ballantine, 2004:115 e.v.). Swart intellektuele soos Mamphela Ramphele, Sipho Seepe en Xolela Mangcu het skerp kommentaar begin lewer op die regeringsbeleid en op kwessies soos voortgesette armoede, VIGS en wapentransaksies. Populêre kunstenaars het weereens op protestemas begin fokus en het begin sing van die verraad teenoor armes, die verryking van diegene in magsposisies en van geïnstitusionaliseerde korrupsie. In "Sê-sê" (Ge-trans-for-meer, 1996) blameer Johannes Kerkorrel "die vet sotte op die rooi tapyt" en identifiseer hy met diegene wat onder die nuwe bestel ly. In "Die stad bloei vanaand" (Die Ander Kant, 2000) verwys hy metafories na die "droom" van die nuwe Suid-Afrika wat "gesteel" is:

Slaap liggies vanaand, wees waaksaam vanaand

Die kriminele kom sag soos 'n dief in die nag

Steel die huis rot en kaal en hardloop weg in die nag

Met die droom van ons nuwe Suid-Afrika

Selfs regsradikale elemente het binne populêre musiekvorms gestalte aangeneem. Die Afrikaanse groep Battery 9, wie se musiek beskryf kan word as 'n tipe "industriële dansgenre" (Ballantine, 2004:119), sluit op hul album Wrok (1998) die snit "Blaas hom" in. Die klankbaan suggereer geluide van 'n tipiese Suid-Afrikaanse stad met sirenes en blaffende honde; die sanger kletsrym in Afrikaans oor sy woede oor 'n herhaalde diefstal en oor sy wraak deur twee inbrekers te skiet. Dit is veelseggend dat hierdie album die prys-

7 Die metaforiese verwysing na Moses as politieke bevryder is dikwels aangewend binne spirituals; 'n voorbeeld is "When Israel was in Egypt's land", ook bekend as "Go down, Moses". 
wenner in die kategorie "Best Rock Album" van die 1998 South African Music Award was.

\section{Herinterpretasies van Afrikanerskap}

As verteenwoordigend van meer onlangse ontwikkelings binne die plaaslike musiekterrein kan die platejoggie Heine du Toit (onder die verhoognaam, D.J. Opperman) gesien word as een van die "hervertolkers" van Afrikaneridentiteit waarna Ballentine (2004) en andere verwys (vgl. veral Marlin-Curiel, 2003). Opperman se musiek kombineer kragtige simbole van Afrikanerdom - onder meer dokumentêre beeldmateriaal van Paul Kruger, Hendrik Verwoerd en P.W. Botha - met gekommersialiseerde rave-musiek. Hierdie "multimedia kultusavontuur", soos Opperman dit beskryf, is onder die titel "Aikonoklasme" by die rave-konsert Transmissie aangebied wat in Desember 1999 by Barn Celos in Melkbosstrand plaasgevind het. Die produksie het ook gedurende Mei 2000 deel gevorm van die Soft Serve II ("Art at Play")-aanbieding by die Nasionale Kunsgalery in Kaapstad (Marlin-Curiel, 2003:55 e.v.).

Ten spyte van politieke ondertone is daar in Opperman se kuns 'n duidelike wegbeweeg van die doelwitte van die alternatiewe beweging van die tagtigerjare. Vir die aanbieders het Transmissie suiwer om vryheid en plesier gegaan. Hierdie kuns-"happening" het wit, bruin en swart Afrikaanssprekende musikante oor kultuur- en rassegrense heen bymekaargebring. Die joernalis Michelle Matthews (1999) merk verder op dat Opperman se "Aikonoklasme" Afrikaans in 'n radikaal nuwe konteks plaas: die "taal van die onderdrukker" funksioneer nou as die lingua franca van byderwetse digitale musiekbelewing. Soos Manie Spamer (in Marlin-Curiel, 2003:56) dit stel, is Afrikaans binne hierdie raamwerk nie meer 'n "heilige uitverkore taal" nie, maar 'n "veelsydige, moderne en uiters plooibare stuk kommunikatiewe gereedskap". Hierdie situasie is moontlik, want "(w)at gesê moes word, is reeds gesê. Dit is nou tyd vir mense om hul vryheid te geniet".

Opperman se rave-avonture vertolk Afrikaneridentiteit egter nie alleen vanuit die hede nie, maar ook sterk vanuit die vormende invloed van die verlede (Marlin-Curiel, 2003:56 e.v.). Die "boodskap" van sy produksies is dat die tyd ryp is vir 'n jonger geslag Afrikaners om hul kulturele en persoonlike identiteit sonder selfbewustheid of skuldgevoel op te eis. Hy beleef politieke toesprake soos dié van D.F. Malan as sowel negatief en positief. Die "helde" van sy jeugjare wat hy in sy klankmengsel siteer, sluit die rugbykommentator Gerhard Viviers en die storieverteller Dana Niehaus in. Marlin-Curiel 
(2003:63) tipeer hierdie herinterpretasie van Afrikanerskap as "'n terugkeer na onskuld".

Die musiekstyle wat tydens Transmissie gehoor is, omvat enigiets vanaf Afrikaanse genres soos goema- en boeremusiek tot by kosmopolitaanse rave-musiek en Afro-jazz. Hierdie kulturele sintese dui op ' $n$ strewe na aanvaarding eerder as verandering. Dit is ' $n$ tendens wat ook duidelik merkbaar is by kunstenaars wat hierbo bespreek is. Gevolglik het talle voorbeelde van 'n vermenging van rock of ander wit style (soos boeremusiek) met plaaslike swart idiome soos marabi, kwela en mbaqanga binne die kommersiële musiekterrein na vore getree. As ideologiese afskynsels mag hierdie hibridiese style geïnterpreteer word as getemperde kulturele en heuristiese oortredings, wat dui op die formasie van nuwe, min of meer vloeibare identiteite (vgl. Ballantine, 2004:109-112).

\section{Nostalgie verklank}

'n Terugblik na Johannes Kerkorrel en die tagtigerjare se alternatiewe Afrikaanse beweging maak dit duidelik dat die stryd in daardie stadium gegaan het om 'n ondermyning van Afrikaans as simbool van Afrikanermag. Daarmee saam is die patriargale beeld van Afrikanermanlikheid ondermyn en belaglik gemaak. Hierteenoor veg die huidige alternatiewe Afrikaanse beweging vir die vryheid om nuwe kulturele formasies onbevange te verklank, asook teen ' $n$ stigmatisering van die taal (Marlin-Curiel, 2003:72). Ten spyte van politieke ondertone en die uitoefening van sosiale kritiek, suggereer die nuwe konteks steeds iets van 'n karnaval-atmosfeer waarbinne daar ongedwonge oor kulturele begrensings heen "feesgevier" word.

Word daar weer teruggekyk na Johannes Kerkorrel se eerste album in die nuwe Suid-Afrika, Cyanide in the Beefcake (1994), bieg hy dat dit 'n verligting is om te skei van die politieke weë van die Afrikanervolk en daardie las van sy skouers af te werp (Botha, 2003:21). Dit is interessant om daarop te let dat Kerkorrel slegs in enkele gevalle van plaaslike swart musikale idiome gebruik maak, of soms net momenteel daaraan herinner. In die oorgrote meerderheid van sy tekste is kwasi-Amerikaanse rock- of blues-style aanwesig en soms ook 'n gospelidioom (vgl. "Sê-sê" in Ge-trans-for-meer, 1996). Een van sy roerendste bydraes is sy verwerking van die tradisionele Afrikaanse volksliedjie "Al lê die berge nog so blou" (Tien jaar later, 
1998). 8 Terwyl die woorde effe aangepas is - Kerkorrel het dié lied vir sy pa gesing ná sy pa se dood - word 'n nuwe interpretatiewe konteks gekonstrueer deur middel van 'n reggaestylbegeleiding. Visuele materiaal wat in 'n DVD-weergawe bygevoeg is, omvang sowel Afrikaner- as "Afrika"-identiteite. Die verband met die verlede is mities-nostalgies, terwyl die bittersoet metafoor van die "blou berge" Rabie se melankoliese natuur op hoogs persoonlike wyse blootlê. Om Ricoeur (1995:4) se woorde nogmaals op te roep: hierdie teks sou inderdaad gelees kon word as 'n teer bemiddeling tussen "die bewussyn van vryheid" en "die gebrokenheid van onvervulde begeerte".

Hoewel Ricoeur (1995:13) die rol van die metafoor in die kreatiewe "herskrywing" van individuele realiteit beklemtoon, glo hy dat die self as hervergestalte identiteit uiteindelik deur middel van narratief gekonstrueer word. Hy onderskei tussen die ipse- en die idemidentiteit, waarvan eersgenoemde beskou word as die projek om 'n lewe te interpreteer deur middel van 'n voortdurende herfigurering van narratiewe wat deur die subjek toegeëien word. Die idemidentiteit wys op 'n selfonderhoudende permanensie en ononderbroke kontinuïteit oor die verloop van 'n lewe heen. Hierdie gesigspunt beskou identiteit nie as staties of monolities nie, maar as 'n steeds veranderende en transformerende fenomeen van betekenis. As sodanig opponeer dit fundamentalistiese en natuurkundiggeoriënteerde verklarings van identiteit, maar ook dié wat berus op anti-cogito historiserende postmoderne re-artikulasies. In laasgenoemde is die self ' $n$ gebroke, willekeurige samestelling van kontingente en idiosinkratiese behoeftes en invloede (vgl. veral Rorty, 1980:4).

'n Direkte toepassing van Ricoeur se denke op Ralph Rabie se "lewensteks" loop sonder twyfel die gevaar van vereenvoudiging. Nietemin kan dit nie ontken word dat hierdie sanger 'n soms onwillige openbare figuur was, wat genadeloos deur die pers van sy privaatheid ontneem is nie. Hy was dikwels die oorsaak van kontroversie, nie alleen as die leier van die alternatiewe Afrikaanse protesbeweging in musiek nie, maar ook as gevolg van sy onstuimige private lewe. Hy het sy visie vir 'n nuwe Suid-Afrika en sy liefde vir die Afrikaanse taal poëties verwoord. Sy artistieke en persoonlike identiteit is deurlopend "herfigureer", en, in Ricoeur se retoriek, "herskryf". Nietemin kan sy lewensverhaal as 'n ononder-

8 Rabie se grafskrif is 'n sitaat uit hierdie liedjie: "Al lê die berge nog so blou / jou woorde sal ons steeds onthou" (vgl. Pretorius, 2004:121). 
broke kontinuïteit gekonstrueer word. Hiervan spreek sy eie tekste wat hy nagelaat het, asook dié van sy naastes en mede-kunstenaars, soos vergestalt in Pretorius (2004) se onlangse biografie, asook die Johannes Kerkorrel-gedenkkonsert. Binne hierdie kontekste mag sy diepe patriotisme gelees word as 'n deurlopende biografiese draad van selfgedagtenis wat sy lewe en werk omspan.

Die "lees" van Kerkorrel se musiek as semiotiese entiteit steun op teoretisering binne die resente musikologie wat genre interpreteer as ' $n$ bepaalde kartering van ideologiese inhoud. 9 Laasgenoemde impliseer dat die interne strukturering van musikale parameters nie as 'n diskrete, "uiterlik-formele" dimensie van musiek gesien word nie, maar eerder as ' $n$ transkodering van sosiale dinamika. Binne hierdie konteks presenteer Kerkorrel se eklektiese aanwending van musikale styl en genre - en met name sy algemene vermyding van "plaaslike" idiome - 'n tergende vraagstuk. Ofskoon Kerkorrel dikwels van rockstyle gebruik gemaak het en by geleentheid van reggae - en hierdie idiome met protes en sosiale kritiek verbind word - is sy aanwending daarvan getemper en kommersieel ingeklee. Indien musikale genre dus as ideologiese "afskynsel" gelees word, dui Kerkorrel se gebruik daarvan paradoksaal op globaliserende middelklassentimente.

Nietemin het Kerkorrel se musiek vanaf die tagtigerjare 'n belangrike samebindende en mobiliserende krag binne die plaaslike musiekterrein gevorm. Meer onlangs kies talle Afrikaners binne ' $n$ steeds transformerende Suid-Afrikaanse samelewing die opsie van "selfbannelingskap" - sommige letterlik deur middel van emigrasie, andere figuurlik deur middel van 'n onttrekking uit die samelewingsforum. Christopher Ballantine (2004:124) identifiseer hierdie tipe gemaskerde "identiteit-in-skuiling" as "voortvlugtend". Die Afrikaanse sanger Valiant Swart se lirieke bied 'n voorbeeld van temas wat fokus op rusteloosheid, ontworteling of die onbekende. Sy narratiewe beeld dikwels verlies uit - ook verlies aan identiteit. In een van sy populêrste liedjies, "Die mystic boer" (1996), word die idee van Afrikaneridentiteit as sodanig bevraagteken. In die album Deur die Donker Vallei (1999) skets hy metafories 'n vreemde land waar identiteit nie langer 'n gegewe is nie ("gaan vra vir die mense in die strate / waar kom jou nuwe naam vandaan").

lewers tussen D.J. Opperman se kultiese rave-avonture en Valiant Swart se mistieke nostalgie ontstaan die vraag of hierdie (en

9 Sien Adam Krims (2000) en Viljoen (2004a) asook Viljoen (2004b). 
soortgelyke) postapartheid-herinterpretasies van wit Afrikanerskap nie maar slegs as ontvlugting beskou kan word nie. Of maskeer hierdie alternatiewe vorme van selfheid nuwe, eksklusiewe vorme van Afrikanernasionalisme? Hoe kan die oënskynlik kritieklose aanwending van inklusiewe, selfs globaliserende kommersiële musiekstyle binne hierdie raamwerk verklaar word? Hierdie kwessie sou produktief hanteer kon word deur 'n musikaal-gedetailleerde teksstudie wat gebruik maak van die filosoof Johann Visagie (1994 en 1996) se tegnies-teoretiese beginsel van die hipernorm. Laasgenoemde is ' $n$ metodologiese stuk gereedskap waarmee dominasieverhoudings binne 'n ideologie-kritiese diskoersanalise blootgelê kan word, en waardeur ideologiese verwrongenheid na die oppervlak gebring word. In terme van botsende ideologiese "verbintenisse" sou 'n dergelike analise dien tot 'n spekulatiewe begronding van watter tekstuele parameter (lirieke of musiek, in hierdie geval) "die waarheid praat" (of, in Visagie se terme, betekenis domineer). ${ }^{10}$

Watter afleiding sou ten slotte binne hierdie veelvoudigheid van diskoerse gemaak kon word oor die posisie van Afrikaans as identiteitsvormende ekspressie van hedendaagse populêre musiekvorme? Marlin-Curiel (2003:72) voer aan dat Afrikaans, méér as enige ander Suid-Afrikaanse taal, 'n gevegsterrein word vir groeperings wat vorm rondom ras, klas en etnisiteit. Die konstruksie van 'n alternatiewe, inklusiewe Afrikaanse identiteit mag in die toekoms 'n kwessie van fisieke sowel as kulturele oorlewing word. Die toeëiening van nuwe interpretasies van taal en van selfheid - en die bemiddeling hiervan deur musikale styl en genre - sou een van die mees werkbare ruimtes vir demokrasie-in-wording kon wees. Indien demokrasie egter op materiële sowel as diskursiewe vlak moet realiseer, noodsaak dit die konstruksie (en rekonstruksie) van sosiale identiteite wat moreel verantwoordbaar is in terme van die hede sowel as die verlede.

\section{Geraadpleegde bronne}

ABBINNETT, R. 2003. Culture and identity: critical theories. London: Sage.

ALBERTINI, B. LEE, B., MILLNER, M., PAVILLE, K., RUTKOWSKI, A., \& WAGNER, B. 2000. Introduction: is there life after identity politics? New Literary History, 31(4):621-626.

BAINES, G. 2004. Popular music and narratives of whiteness in apartheid South Africa. Unpublished paper.

10 Sien Viljoen (2004b) vir 'n teoretiese raamwerk wat van toepassing is op multimediavoorbeelde en waarby Visagie se metodologie inspeel. 
BALLANTINE, C. 2004. Re-thinking 'whiteness'? Identity, change and 'white' popular music in postapartheid South Africa. Popular Music, 23(2):105131.

BOTHA, N. 2003. JK se musiek leef voort. Die Taalgenoot, 72:20-21.

BRANNIGAN, J. 1998. New historicism and cultural materialism. New York: St. Martin's Press.

BRYNARD, K. 1999. Johannes doop die taal vry. Insig: 16-18, Nov.

BYERLY, I. 1998. Mirror, mediator and prophet: the music indaba of lateapartheid. Ethnomusicology, 42(1):1-44.

DERRIDA, J. 1981. Positions. A. Bass (tr.). Chicago: University of Chicago Press.

FOUCAULT, M. 1972. The archaeology of knowledge. London: Tavistock.

HALL, S. \& DU GAY, P., eds. 1996. Who needs identity? Questions of cultural identity. London: Sage.

KRIMS, A. 2000. Rap music and the poetics of identity. Cambridge: Cambridge University Press.

MARLIN-CURIEL, S. 2003. Sampling the past: sound, language and identity in the new South Africa. (In Wasserman \& Jacobs, S. Shifting selves: postapartheid essays on mass media, culture and identity. Cape Town: Kwela Books: p. 55-78.)

MATTHEWS, M. 1999. Trance met 'n missie. Daily Mail and Guardian: 17 Des.

MULLER, S. 2002. Kartetse: taal en stem bots in Kerkorrel se musiek. Die Burger: 20 Nov.

OLDS, L.E. 1992. Metaphors of interrelatedness: towards a systems theory of psychology. New York: State University of New York Press.

PRETORIUS, W. 2004. Kerkorrel. Kaapstad: Tafelberg.

RICOEUR, P. 1995. Figuring the sacred: religion, narrative and imagination. D. Pellauer, tr. and M.I. Wallace, ed. Minneapolis: Fortris.

RORTY, R. 1980. Freud, morality, and hermeneutics. New Literary History, 12(1):177-186.

SAMPSON, E.E. 1990. The deconstruction of the self. Shotter, J. \& Gergen, K.J. (eds). (In Texts of identity. London: Sage. p. 1-19.)

VILJOEN, M. 2004a. Ideology and textuality: speculating on the boundaries of music. Scrutiny, 29(1):68-87.

VILJOEN, M. 2004b. Questions of musical meaning: an ideology-critical approach. International Review of the Aesthetics and Sociology of Music, 35(1):3-28.

VISAGIE, P.J. 1994. The name of the game in ideology theory. Unpublished manuscript, University of the Free State.

VISAGIE, P.J. 1996. Power, meaning and culture: John Thompson's depth hermeneutics and the ideological topography of modernity. South African Journal of Philosophy, 15(2):73-83.

\section{Diskografie}

BATTERY 9. 1998. Wrok. Tic Tic Bang Bang BANGCD 138.

GOOSEN, ANTON. 1992. Danzer. Gallo CDHUL 40288.

GOOSEN, ANTON. 1996. Bushrock (of a White Kaffir of Africa). Gallo CDGMP 40693.

JAMES PHILLIPS \& THE LURCHERS. 1993. Sunny Skies. Shifty Music SMSPCD 819. 
KERKORREL, JOHANNES. 1989. Eet Kreef. Shifty Music SHIB32.

KERKORREL, JOHANNES. 1992. Bloudruk. Tusk TUCD 21.

KERKORREL, JOHANNES. 1994. Cyanide in the Beefcake. Tusk TUCD 33.

KERKORREL, JOHANNES. 1996. Ge-trans-for-meer. Tusk WOND 142.

KERKORREL, JOHANNES. 1998. Tien jaar later, 2000. Gallo GWVCD 4.

KERKORREL, JOHANNES. 2000. Die Ander Kant. Gallo GWVCD 28.

KERKORREL, JOHANNES. 2003. 'n jaar later ... in die Staatsteater. Johan Badenhorst Kew Productions JBDVD04.

KOMBUIS, KOOS. 1990. Niemandsland and Beyond. JNS Music.

RAUCH, LAURIKA. 1995. Hot Gates. Tusk WOND 145.

SWART, VALIANT. 1996. Die Mystic Boer. Wildebeest Records SWART 001.

SWART, VALIANT. 1999. Deur die Donker Vallei. Wildebeest Records SWART 004.

\section{Kernbegrippe:}

Johannes Kerkorrel

neo-rekonstruksionistiese filosofie

postapartheid-Afrikaneridentiteit

protesmusiek

tekstuele analise

\section{Key concepts:}

Johannes Kerkorrel

neo-reconstructionist philosophy

post-apartheid Afrikaner identity

protest songs

textual analysis 
